\title{
Comparative analysis of between trading volume activities pre with post event tax amnesty
}

\author{
Bayu Teguh Imani, Satia Nur Maharani* \\ Universitas Negeri Malang, Jl. Semarang No. 5 Malang, Jawa Timur, Indonesia \\ *Corresponding author, Surel: satia.nur.fe@um.ac.id
}

Paper received: 2-2-2021; revised: 20-2-2021; accepted: 27-2-2021

\begin{abstract}
This study aims to determine the difference of Trading Volume Activity that exceed before and after the determination of tax amnesty policy and to figure out the existence of abnormal return formed before and after the determination of the tax amnesty. This study uses the Events Study method with 100 days observation for the estimation period and 15 days for event period. The study used a group of perception banks that listed in BEI in 2016 period as population and 22 selected stocks to be sampled by using saturated sampling method. During the observation period, positive and negative abnormal returns with fluctuating movements were formed. Trading Volume Activity changes between before and after-tax amnesty policy. From these two results, it can be concluded that there was leakage of information before the event published that indicates the form of market efficiency of Indonesia is half strong (semi strong form). Further research is suggested to use the calculation method and time different from this research to obtain more accurate results.
\end{abstract}

Keywords: efficiency market hypothesis; tax amnesty; trading volume activity; abnormal return

\section{Introduction}

Random walk implies that a series of stock price changes are independent of past price changes, so that historical data cannot be used to predict future stock price movements (Fama, 1965b). The stock price on a certain day reflects market conditions on the same day and is not related to market conditions on the previous day. The random walk market price behavior is the basis for Fama in developing the concept of market efficiency which shows that investors are rational, competing with each other to eliminate the difference between actual return and the intrinsic value of shares. New information is a source of fundamental analysis, which is then responded by investors, thus changing the intrinsic value and affecting stock prices. According to Fama (1965b), in a situation where new information is published, the real price (intrinsic value) will immediately change and move towards a new level of intrinsic value due to the rational behavior of investors. The neutralization process of the difference between actual return and intrinsic value causes actual return to fluctuate randomly around its intrinsic value (Yalçın, 2010). The events that have been reported recently are the government's new policy regarding tax amnesty or what is known as tax amnesty. Investors are thought to have responded to the policy because in addition to the policy character which is closely related to potential the increase in state income from tax amnesty is also the perception bank appointed to collect repatriation funds are listed members in the capital market.

Tax Amnesty is one of the information that comes from government policy and becomes an economic trending topic at the end of June to July 2016. Law number 11 of 2016 on tax amnesty article 8 paragraph 6 states that the transfer of assets to be transferred to the country must be invested in the time frame at least 3 years. Continued in article 12 paragraph 3 which explains that one way of investing in assets is financial investment in a Perception Bank. It is 
stated in Decree of the Minister of Finance (KMK) Number 600 / KMK.03 / 2016 concerning the Determination of a Perception Bank acting as a ransom recipient in the context of implementing tax amnesty, which was released on 18 July 2016. Effect of tax remission policies ( Tax Amnesty) for issuers bank category perception receive income from the repatriation of funds, is a capital increase resulted in increased profitability and growth of the company. Meanwhile, the increase in the amount of company profit (profit) is directly proportional to the dividend distributed by the company to shareholders. This has led to investors' buying interest in company shares (perception bank) which has led to the formation of abnormal returns and trading volume activity. This research was conducted to determine the reaction or market response and capital market behavior both before and after economic events ( tax amnesty policy ) on stock activities by using an event study.

Fama defines an efficient market that will occur if the stock price is relevant to the entire set of market information. This information is divided into three categories, namely past information, information published to the public and all information including private company information (Jarrow and Larsson, 2011). In connection with the availability of information in the above three categories, then Fama efficient market split in three levels namely weak form efficient market ( weak form ), half-strong form efficient market ( semistrong form ), and the strong form of the efficient market ( strong form ). An efficient market has a weak form (weak form ) if the current stock price only reflects all past information such as historical stock prices, trading volume and rates of return for the previous period (Bodie et al ., 2007). An efficient market has a semi strong form if prices not only reflect past information, but also reflect all relevant public information (Bodie et al ., 2007). Public information includes issuers' earnings, dividend announcements, market ratios, stock plits announcements , economic and political news (Jarrow and Larsson, 2011). According to the semi strong form concept, investors are unlikely to get abnormal returns from publicly available information. Financial reports do not have any benefits because as a form of public information, financial reports spread immediately in the market and are quickly reacted by all investors.

According to Fama, the most perfect market efficiency is a strong form market efficiency . The market is said to be a strong form if prices are able to reflect all information both past and public information and private information (Yalçın, 2010). Market efficiency at this level has the maximum power to erase abnormal returns, even those originating from insider trading. All private information is freely available in the market, so there is no gap for information asymmetry through insider practices that can produce abnormal returns (Bodie et al ., 2007). The tax amnesty concept put forward by Simon (2012) is a policy to provide opportunities for taxpayers (taxpayers) to pay their tax arrears without any penalties. Fisher (1999) argues that generally, tax amnesty is only given once with a relatively limited period of time, especially before stricter law enforcement measures are taken. tax amnesty is also often used to obtain correct data on taxpayers (taxpayers), so that in the future it can be used as a basis for improving law enforcement and extracting taxes that should be received by the state. According to Alm and Benno (2004) the tax amnesty (sunset policy) has positive aspects, such as the state being able to obtain additional revenue from ransom and company books can be started from new figures that are clean from tax evasion practices. The advantage is expected if the tax amnesty policy is implemented will be able to encourage the entry of funds from abroad which in the long term can be used as an investment driver which in turn is useful to stimulate the national economy (Ngadiman and Huslin, 2015). 


\section{Method}

The research design used is an event study. An event study is a study of the effect of events on stock prices in the capital market by observing stock price movements in the period before and after the event (Khotari and Warner, 1997). Eventstudy divided into two periods, namely the period of time estimated ( estimation period ) and the observation period ( windows period ) which can be described as follows:

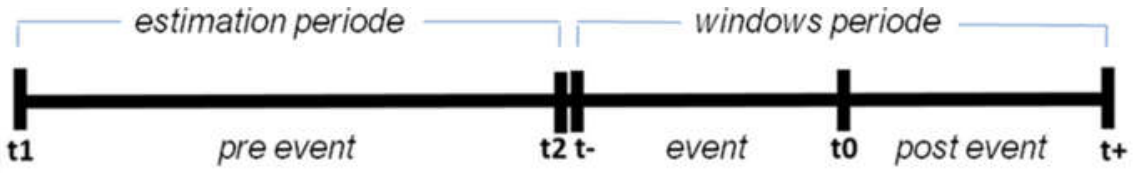

Figure 1. Design Event Study

Estimation period occurs at $\mathrm{t} 1$ to $\mathrm{t} 2$, the window period before the event (pre event) with the symbol t-, events ( event) $t$ - to $t 0$, and after the event ( post event) with the symbol $t+$. The length of the estimated period is longer than the time span of the observation period. The length of time used as the estimation period is 100 days to 250 days, but there are no special provisions that require taking an estimated period of 100 days to 250 days (Jogiyanto, 2012). Researchers often use the estimation period below 100 days and the limitations of the available data are limited. the event period, the time between the pre event $(\mathrm{t}-)$ to the event $(\mathrm{t}$ 0 ) must be the same as the time span between the event $(t 0)$ to after the event $(t+)$.

The length of the general observation period is 3 days to 250 days for daily data and 30 months to 60 months for monthly data (Jogiyanto, 2012: 58). Observation of abnormal return (AR) with trading volume activity (TVA) is carried out on the day around the event, namely the day of the event, 7 days before and 7 days after the event. In this study, the estimation period method is used for 100 days, the collection is carried out from 16 March 2016 to 23 June 2016. In addition, the event date occurs on 1 July 2016, so the observation period of the event (event period) is carried out for 7 The day before the event (pre event), namely from 22 June 2016 to 30 June 2016, and 7 days after the event (post event) counting from 11 July 2016 to 19 July 2016.

The calculation for trading volume activity (TVA) uses the calculation of the average trading volume activity during the observation period, namely the estimation period with the event period adopted from Foster (1986: 375) . Signs of the market reacting, namely seeing that the average trading volume activity at the event period is higher than the average trading volume activity in the estimation period. The average trading volume can be calculated using the formula:

$$
\bar{x} T V A=\frac{\Sigma \text { Trading Volume Activity pada waktut }}{N}
$$

In order for the stock price to produce abnormal return (AR) data and find out the market reaction, the following steps are taken:

1. Calculating Realized Return

$$
\text { Return Saham }=\frac{P-P T-1+D T}{P T-1}
$$


Where?

P: the price of security

$\mathrm{I}$ : in the event period $\mathrm{t}$.

$\mathrm{Pi}, \mathrm{t}-1$ : the price of security I in the event 1 period. Di, $\mathrm{t}$ : dividend at the end of the period.

\subsection{Menghitung return ekspektasi}

$$
E\left(R_{i}\right)=\sum_{j=1}^{5}\left(R_{i j} \cdot p_{i}\right) / T
$$

E (R i): Return on expected security for the ith security for period t R ij : Return on realization of the $i$-th security after estimated period $j$

$\mathrm{T}$ : The length of the estimated period, between $\mathrm{t} 1$ and $\mathrm{t} 2$

\subsection{Calculating the Abnormal Return}

$$
\text { RTN it }=\mathrm{Ri}, \mathrm{t}-\mathrm{E}(\mathrm{R} \mathrm{i}, \mathrm{t})
$$

RTN it: I-th Abnormal Return on t-event

$\mathrm{R} i$, $t$ : Realized return for the ith security in event period $t$

$\mathrm{E}(\mathrm{R} \mathrm{i}, \mathrm{t})$ : Expected return for the i-th security in event period $\mathrm{t}$

This study uses a population of all perception banks listed on the Indonesia Stock Exchange in the 201 period. The total population is 24 issuers' stocks and all of them are used in this study so that it uses the total sampling technique. Data analysis regarding the difference in trading volume activity between Pre and Post Event tax amnesty and the abnormal returns formed during the event period was carried out using descriptive statistics. Data processing uses Microsoft Excel tools by entering formulas according to predetermined steps.

\section{Result and Discussion}

\subsection{Abnormal Return}

The calculation of abnormal return aims to determine the market reaction to the incidence of tax amnesty policy determination by observing the abnormal returns formed during the event period. The calculation of abnormal return includes the following steps: 1. Calculation of realization return. The calculation of realized return produces positive, negative realizable returns and there are several securities that produce zero (0) realized return. The following is a recapitulation of the results of the realization of return calculations that have been done

Table 1. Calculation Results of Return Realization

\begin{tabular}{llllllllllllllll}
\hline & $\mathbf{t}-\mathbf{7}$ & $\mathbf{t}-$ & $\mathbf{t}-$ & $\mathbf{t}-$ & $\mathbf{t}-$ & $\mathbf{t}-$ & $\mathbf{t}-$ & $\mathbf{t 0}$ & $\mathbf{t + 1}$ & $\mathbf{t + 2}$ & $\mathbf{t + 3}$ & $\mathbf{t + 4}$ & $\mathbf{t + 5}$ & $\mathbf{t + 6}$ & $\mathbf{t + 7}$ \\
& & $\mathbf{6}$ & $\mathbf{5}$ & $\mathbf{4}$ & $\mathbf{3}$ & $\mathbf{2}$ & $\mathbf{1}$ & & & & & & & & \\
\hline Positif & 11 & 4 & 2 & 7 & 6 & 15 & 12 & 12 & 12 & 16 & 8 & 8 & 8 & 5 & 3 \\
Negatif & 1 & 6 & 11 & 8 & 10 & 3 & 4 & 7 & 4 & 3 & 10 & 8 & 5 & 5 & 12 \\
0 & 12 & 14 & 11 & 9 & 8 & 6 & 8 & 5 & 8 & 5 & 6 & 8 & 11 & 14 & 9 \\
\hline
\end{tabular}

Table 1. provides information that during the event period most forms of return realized positive with the highest number of 16 companies that occurred in post-event day $2(t+2)$, 
Return realization of the highest negative response to the last day of post event with a total of 12 companies, while for Realized return equal to zero (0) mostly occurs on the sixth day of the pre event $(t-6)$ and the post event on the sixth day $(t+6)$ of 14 companies. From this information, it can be seen that the share price during the event period fluctuates. A positive return on realization shows that the company's stock price has increased from the previous day, on the contrary, if a negative realization return is formed, it indicates that the stock price has decreased from the previous day, whereas if the realized return is equal to zero $(0)$ it indicates that the security does not provide a return.

\subsection{Calculation of expected return}

Data expected return is calculated by multiplying the total returns realized during the estimation period divided by the number of days that generate information that from the overall sample of 24 stocks generated 12 returns the realization of positive, 10 return negative expectations, and the two companies do not generate return expectations or return expectations equal to zero. The results of calculating the expected return are as follows:

Table 2. Calculation Results of Expected Return

\begin{tabular}{llll}
\hline StockCode & $E[\mathrm{Ri}, \mathrm{j}]$ & StockCode & $\mathrm{E}[\mathrm{Ri}, \mathrm{j}]$ \\
\hline INPC & 0.000201 & BBMD & -0.000095 \\
BBKP & -0.001175 & BABP & 0.001971 \\
BNBA & 0.000390 & BBNI & -0.000001 \\
BBCA & -0.000106 & BBNP & 0 \\
BNGA & -0.001793 & NISP & 0.000570 \\
BDMN & 0.000842 & BNLI & 0.001138 \\
BCIC & 0 & BBRI & -0.000630 \\
BMRI & -0.000378 & BSIM & 0.003421 \\
BMAS & -0.002633 & BBTN & 0.001945 \\
MAYA & -0.001775 & BTPN & 0.001822 \\
BNII & 0.001981 & SDRA & -0.000683 \\
MEGA & 0.001875 & BGTG & 0.000383 \\
\hline
\end{tabular}

\subsection{Calculation of abnormal return}

Data abnormal return is obtained from the calculation of return realization of reduced return expectations, with results shows in Table 3:

Table 3. Details of Abnormal Return

\begin{tabular}{llllllllllllllll}
\hline & $\mathbf{t}-\mathbf{7}$ & $\mathbf{t}-\mathbf{6}$ & $\mathbf{t}-\mathbf{5}$ & $\mathbf{t 4}$ & $\mathbf{t}-\mathbf{3}$ & $\mathbf{t}-\mathbf{2}$ & $\mathbf{t}-\mathbf{1}$ & $\mathbf{t ~ 0}$ & $\mathbf{t + 1}$ & $\mathbf{t + 2}$ & $\mathbf{t + 3}$ & $\mathbf{t + 4}$ & $\mathbf{t + 5}$ & $\mathbf{t + 6}$ & $\mathbf{t + 7}$ \\
\hline Positif & 16 & 8 & 7 & 11 & 10 & 18 & 14 & 9 & 14 & 18 & 9 & 11 & 10 & 11 & 14 \\
Negatif & 6 & 14 & 15 & 11 & 12 & 4 & 8 & 13 & 8 & 4 & 13 & 11 & 12 & 11 & 9 \\
0 & 2 & 2 & 2 & 2 & 2 & 2 & 2 & 2 & 2 & 2 & 2 & 2 & 2 & 2 & 1 \\
\hline
\end{tabular}

Table 3. provides information that during the event period almost all stocks produced abnormal returns, only 2 stocks did not produce abnormal returns, namely Bank Jtrush Indonesia, Tbk. and Bank Nusantara Parahyangan, Tbk. which only resulted in an abnormal return on the 7 th day post event $(7+)$. The existence of stocks whose abnormal return is equal to 0 provides information that investors of the company's shares do not react to events. From the number of positive abnormal returns that are formed more Many compared to negative 
abnormal returns provide information that the market gives more positive responses or accepts the tax amnesty policy set by the government.

\subsection{Calculation of the average abnormal return}

Data on average abnormal returns are collected from each day during the event period by dividing the total abnormal returns by the number of samples providing information that during the event period positive and negative abnormal returns are formed. The abnormal returns formed in the pre event were dominated by positive abnormal returns, only three times negative abnormal returns were formed, namely on $\mathrm{t}-6, \mathrm{t}-5$ and $\mathrm{t}-3$ days. The opposite occurs during the post event where positive abnormal returns are only formed three times, namely at $t+1, t+2$ and $t+7$. From these results it can be concluded that the hypothesis which states that there is an abnormal return between before and after the determination of the tax amnesty policy is accepted. The results of calculating the average abnormal return are as follows:

Table 4. Calculation of the average abnormal return

\begin{tabular}{cccccc}
\hline \multicolumn{2}{l}{ Pre-Event } & \multicolumn{2}{l}{ Event Day } & \multicolumn{2}{l}{ Post Event } \\
\hline $\mathrm{t}-7$ & 0.0069497 & $\mathrm{t} 0$ & 0.0110655 & $\mathrm{t}+1$ & 0.0133447 \\
$\mathrm{t}-6$ & -0.0027206 & & & $\mathrm{t}+2$ & 0.0265172 \\
$\mathrm{t}-5$ & -0.0048697 & & & $\mathrm{t}+3$ & -0.0102053 \\
\hline
\end{tabular}

\subsection{Trading Volume Activity (TVA)}

The trading volume activity (TVA) calculation aims to determine the market reaction by looking at the difference in stock trading volume between before and after the determination of the tax amnesty policy. The calculation is done by looking for the trading volume activity (TVA) of each stock and then continuing to calculate the average trading volume of each day for 7 days before and 7 days after the announcement of the tax amnesty policy. From the results of the calculations that have been done, the following results presented in Table 5:

Table 5. Calculation of trading volume activity (TVA)

\begin{tabular}{lclr}
\hline \multicolumn{2}{c}{ Pre-Event } & \multicolumn{2}{c}{ Post Event } \\
\hline $\mathrm{t}-7$ & 0.01652043 & $\mathrm{t}+1$ & 0.018721634 \\
$\mathrm{t}-6$ & 0.00619944 & $\mathrm{t}+2$ & 0.030660498 \\
$\mathrm{t}-5$ & 0.01263385 & $\mathrm{t}+3$ & 0.014205016 \\
$\mathrm{t}-4$ & 0.00575078 & $\mathrm{t}+4$ & 0.010824492 \\
$\mathrm{t}-3$ & 0.01223341 & $\mathrm{t}+5$ & 0.011659557 \\
$\mathrm{t}-2$ & 0.01736466 & $\mathrm{t}+6$ & 0.008864473 \\
$\mathrm{t}-1$ & 0.01989642 & $\mathrm{t}+7$ & 0.018883539 \\
$\bar{x}$ & 0.01294271 & $\bar{x}$ & 0.016259887 \\
\hline
\end{tabular}

Table 5 provides information that the trading volume activity (tva) between before and after the event has changed. It can be seen from the average TVA before the event of 0.01294, increasing after the event to 0.01626 . The increase in the average TVA was 0.00331 . From the results of these studies it can be concluded that the stated hypothesis. There are differences in the average trading volume activity before and after the establishment of the remission of tax policy ( tax Amnesty) is accepted. It is known that there is a difference in the average trading volume of activity between before and after the determination of the tax amnesty policy. The 
average trading volume activity in the period before the event was 0.01294 and in the period after the event it increased to 0.01626 . Meanwhile, the abnormal return formed before and after the determination of the tax amnesty policy is not equal to zero. Thus it can be concluded that the research hypothesis is accepted.

In accordance with the provisions in the Minister of Finance Regulation number 119 of 2016 concerning procedures for transferring taxpayer assets into the Republic of Indonesia and placement in investment instruments on the financial market in the context of interdiction, in article 6 paragraph 2 it is explained that the placement of investment instruments includes deposits, savings, and current account. Then in Law number 11 of 2016 concerning tax amnesty in article 8 paragraph 4 it is explained that the deposit and transfer of assets must go through a perception bank. These two provisions indicate that there will be a lot of funds going to banks, especially banks that have been selected as perception banks.

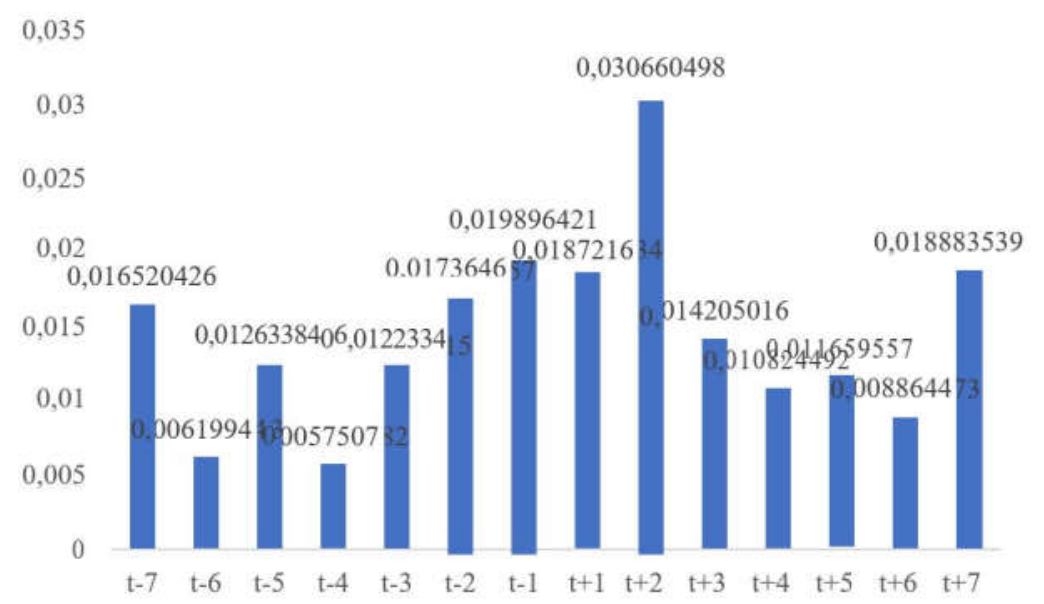

Figure 2. Diagram of the average trading volume activity

The results of calculating trading volume activity (TVA) before and after the event show that the market reacts to the event. In Figure 2 it can be seen that there is a change in the average TVA between before and after the event. The average TVA in the pre-event period was 0.01294 and the post-event period increased to 0.01626 . The highest TVA occurred on the post event day $2(t+2)$ and the last day $(t+7)$. If you look at a glance, the diagram of the TVA between before and after the event has the same height, but the lowest point of the TVA diagram on the day before the event is lower when compared to the lowest TVA diagram after the event and the highest diagram after the event is higher than before the event.

The entry of funds into the perception bank will provide additional capital for the bank. When capital increases, the bank's liquidity will also increase, which will lead to increased company profitability. The good prospects of these perceived banks are a positive signal that will increase investor interest in banking stocks, which are perception banks. Increased profitability will increase the amount of dividend yield that investors will receive. Increased investor buying interest in perceptual banks shares, resulting in an increasing share price so that the amount of capital gain that will be obtained by investors will also increase until an abnormal return is formed. 


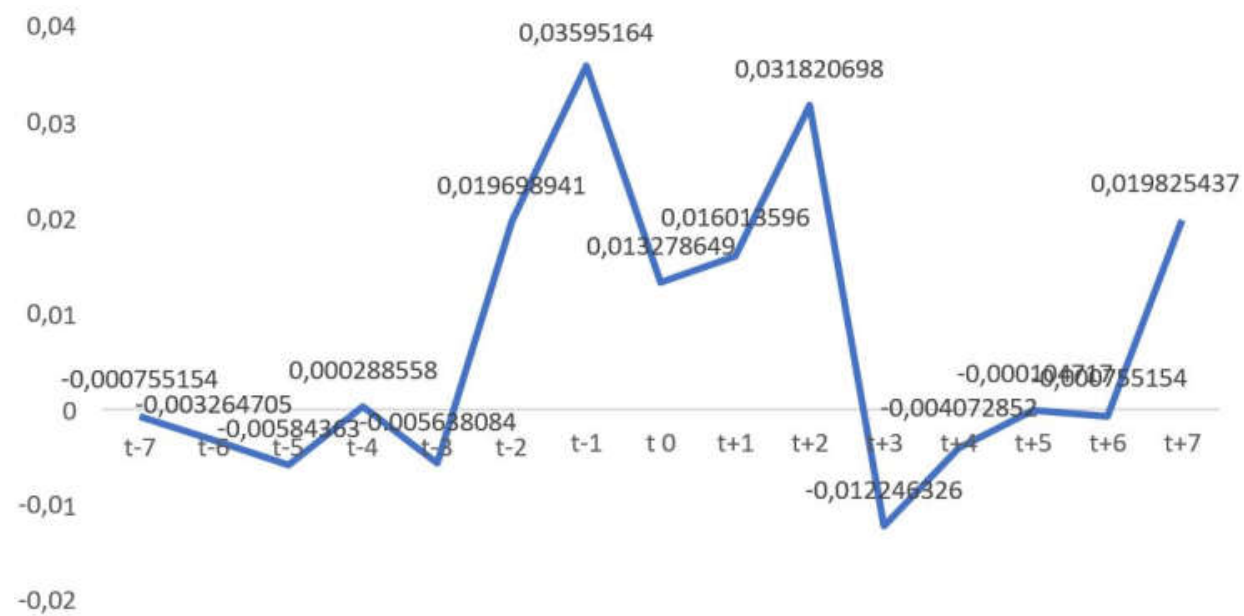

Event Periode

Figure 3. Graph of abnormal return movement

Based on Figure 3, it can be seen that the movement of abnormal returns fluctuates. At the beginning of the observation day, there was no significant movement because the abnormal return formed was still very low. The highest positive abnormal return was formed on the pre event day $1(\mathrm{t}-1)$ of 0.03595 , then on the post event day $2(\mathrm{t}+2)$ was 0.0318 and the last day $(\mathrm{t}$ $+7)$ was 0.0198 . While the lowest negative abnormal return was formed on the 5 th day post event of -0.00010 and the highest was formed on the 3rd day post event $(t+3)$ of -0.0122 . Markets that reacted positively to this policy were strengthened by news during the event period which showed the JCI was always moving in the green zone. As reported by Detikfinance.com on June 30,2016, the JCI closed up to 5,016 and during the period of the incident, the JCI continued to advance in the range of 5,000.

Positive responses from property owners who are abroad are indicated by the large amount of foreign capital entering the Indonesian capital market. As reported by Detikfinance.com on July 13 2016, foreign funds entering the Indonesian capital market starting from June 28, 2016 to July 12, 2016 reached one trillion rupiah. Foreign funds that entered the Indonesian capital market on June 28, 2016 were recorded at 691.319 billion rupiah, the following day it reached 1.712 trillion rupiah and increased the following day to penetrate the figure of 1.737 trillion rupiah. On the day the Tax Amnesty Law was enacted, the amount of incoming foreign funds decreased by only 983.906 billion rupiah and increased again the following day, namely 1.514 trillion rupiah on 11 July 2016 and 1.577 trillion rupiah on 12 July 2016.

This very high increase in trading activity shows that investors are starting to get signals regarding tax amnesty policies long before the day of the event announcement. One of the signals to investors is the mass media. Information regarding the preparation of related parties and the opinions of experts or influential people such as directors of the IDX and OJK regarding tax amnesty is a signal for investors. As long as the incident has not been determined, all news is still in the form of issues, so the signal generated is still not strong. Investors are still cautious when the information received is still in the form of issues, because the good prospects that will result from the event are uncertain. When events are published, good prospects will actually occur. Thus the announcement of events provides a strong signal for investors. It can 
be seen from the movement of the TVA number which was formed higher the day after the announcement of the event.

The difference between TVA before and after the event shows the market reacts to the event. When TVA after the event is higher than before the event, it indicates that the news about this event contains information that can be used as a consideration for making investment decisions. As reported by detikfinance.com where in the days before the event the JCI movement increased and was in the green zone, even remaining in the green zone until after the event. JCI moving in the green zone indicates that the market gave a positive response to events. The green zone indicates that more investors are buying shares so that the market is controlled by buyers

\section{References}

The study uses two indicators, namely abnormal returns and trading volume activity, the conclusion is that the market reacts to events with different explanations. Abnormal return explains that the market reacts with changes in stock prices, where negative abnormal returns represent negative reactions from investors and positive abnormal returns represent positive reactions from investors to events. Meanwhile, trading volume activity explains that the market reacts with changes in trading volume. Changes in trading volume activity before and after the event indicate that the market reacts to the event, whereas if the TVA before and after the event is the same, then the market does not react.

In accordance with Brigham's opinion (2014: 186) regarding signaling theory , every action taken by company management provides a signal about the company's prospects to investors. Actions taken by several banking management in welcoming tax amnesty, such as BNI bank which issued short-term deposits to accommodate repatriation funds, like BRI which prepared its subsidiary engaged in insurance and collaborated with investment management, and Bank Mandiri which conducted socialization on Mandiri securities. as an instrument for collecting repatriation funds (detikfinance.com:Juli 2016), has provided a positive signal regarding an increase in the company's prospects. Positive news reported, such as on the detikfinance.com page, on the days around the event, gave a signal to investors who responded with a positive reaction. Some of the positive news, such as the optimism of banks in welcoming the tax amnesty, the addition of instruments provided by banks to collect repatriation funds and the OJK prediction that child banking will grow by $13 \%$ for the year.

The formation of abnormal returns during the event period and changes in trading volume activity (TVA) after the policy setting event indicate that the Indonesian capital market is in a semi-strong form (semistrong form). In accordance with the characteristics of a semistrong market (semistrong form) where the sooner investors catch the signal, the faster the stock price will change. The more sophisticated technology supports this, because with the sophistication of technology investors can get information quickly so they can respond with news quickly too.

\section{References}

Alm, J., \& Torgler, B. (2006). Culture differences and tax morale in the United States and in Europe. Journal of economic psychology, 27(2), 224-246.

Brigham, E. F., \& Houston, J. F. (2010). Dasar-Dasar Manajemen Keuangan: Essensial of Financial Management Buku 1.

Bodle, Z., Kane, A., \& Marcus, A. J. (2008). Essential of Investment"; The McGraw-Hill Companies. Inc. USA. 
Jurnal Ekonomi, Bisnis dan Pendidikan, 1(2), 2021, 190-199

Fama, E. F. (1995). Random walks in stock market prices. Financial analysts journal, 51(1), 75-80.

Foster, G. (1986). Financial Statement Analysis, 2/e. Pearson Education India.

Muda, M., Ristiana, I., \& Wening, N. (2020). Effect of Sunset Policy, Tax Amnesty, Tax Sanctions, and WhistleBlowing System Against Tax Obligation (An Empirical Study on A Private Vocational Yogyakarta). International Journal of Business, Humanities, Education and Social Sciences (IJBHES), 2(2), 62-67.

Kothari, S. P., \& Warner, J. B. (1997). Measuring long-horizon security price performance. Journal of financial economics, 43(3), 301-339.

Jarrow, R. A., \& Larsson, M. (2012). The meaning of market efficiency. Mathematical Finance: An International Journal of Mathematics, Statistics and Financial Economics, 22(1), 1-30.

Jogiyanto, J. 2015. Portfolio Theory and Investment Analysis: Seventh Edition. Yogyakarta. BPFE - Yogyakarta.

Yalçın, K. C. (2010). Market rationality: Efficient market hypothesis versus market anomalies. European Journal of Economic and Political Studies, 3(2), 23-38. 